\title{
Distribution and diversity of Polyporaceae in Western India: An overview and addition to mycoflora of the Gujarat state
}

\author{
Ajit M. Vasava, Ravi S. Patel, Rina D. Koyani and Kishore S. Rajput \\ Department of Botany, Faculty of Science, The Maharaja Sayajirao University of Baroda, Vadodara 390002, India
}

\section{Article history}

Received: 21 September 2017

Accepted: 28 December 2017

Published: 07 March 2018

(c) Vasava et al (2018)

Editor

K K Sabu

Publisher

Horizon e-Publishing Group

Correspondence

Kishore S. Rajput

曻s.rajpu15@yahoo.com

\begin{abstract}
Extensive fieldwork in different climatic regimes of Gujarat state during last four years resulted in the collection of more than 349 fungal species. Out of these, 37 species from 20 genera were found to be from the family Polyporaceae. Among these, five species are being reported for the first time here as new distribution records. The highest number of species is represented by the genus Trametes while, Cerrena unicolo, Neolentinus kauffmanii, Dichomitus squalens, Panus conchatus and Laetiporus sulphureus possessed single species each.
\end{abstract}

\section{Keywords}

Bracket fungi; fungal diversity; Gujarat; Polyporaceae; Trametes

\section{Citation}

Vasava A M, Patel R S, Koyani R D, Rajput K S. Distribution and diversity of Polyporaceae in Western India: An overview and addition to mycoflora of the Gujarat state. Plant Science Today 2018;5(1):32-38. https://dx.doi.org/10.14719/pst.2018.5.1.353

\section{Introduction}

Fungi are an ancient group of organisms which separated from animals about 900 million years ago (5) that adapted to variety of habitats by altering the hyphal structure, mode of nutrition, including substrates, reproductive structure and growth forms. They are indispensable mediators in recycling the carbon stored in plant material and other organic compounds and are thus an important component of the ecosystem (10). On the flip side, they also cause economic losses in the form of decay and deterioration of forest products and diseases to flora and fauna (7). Lately fungal strains have been used in the productions of enzymes on a commercial scale. White rot Basidiomycetes produce different types of peroxidases and laccases that have potential application in degradation of xenobiotic compounds. Most of the antibiotics available in the market are also obtained from fungi. Intensive research work has been initiated worldwide in search of new and novel biomolecules to combat diseases that plague mankind. Edible fungi are a rich source of nutrition. Many fungi are sources of edible as well as nonedible dyes. In spite of its various applications and importance, studies on fungal diversity of Gujarat state has not received much attention from the scientific community and there is very little published information on the subject (20).

In recent years, a few efforts have been made to document the same from the Gujarat state, but most of the reports are on human pathogen $(3,6$, $8,9,18)$ and agricultural pathogen $(17,24,29)$ but 

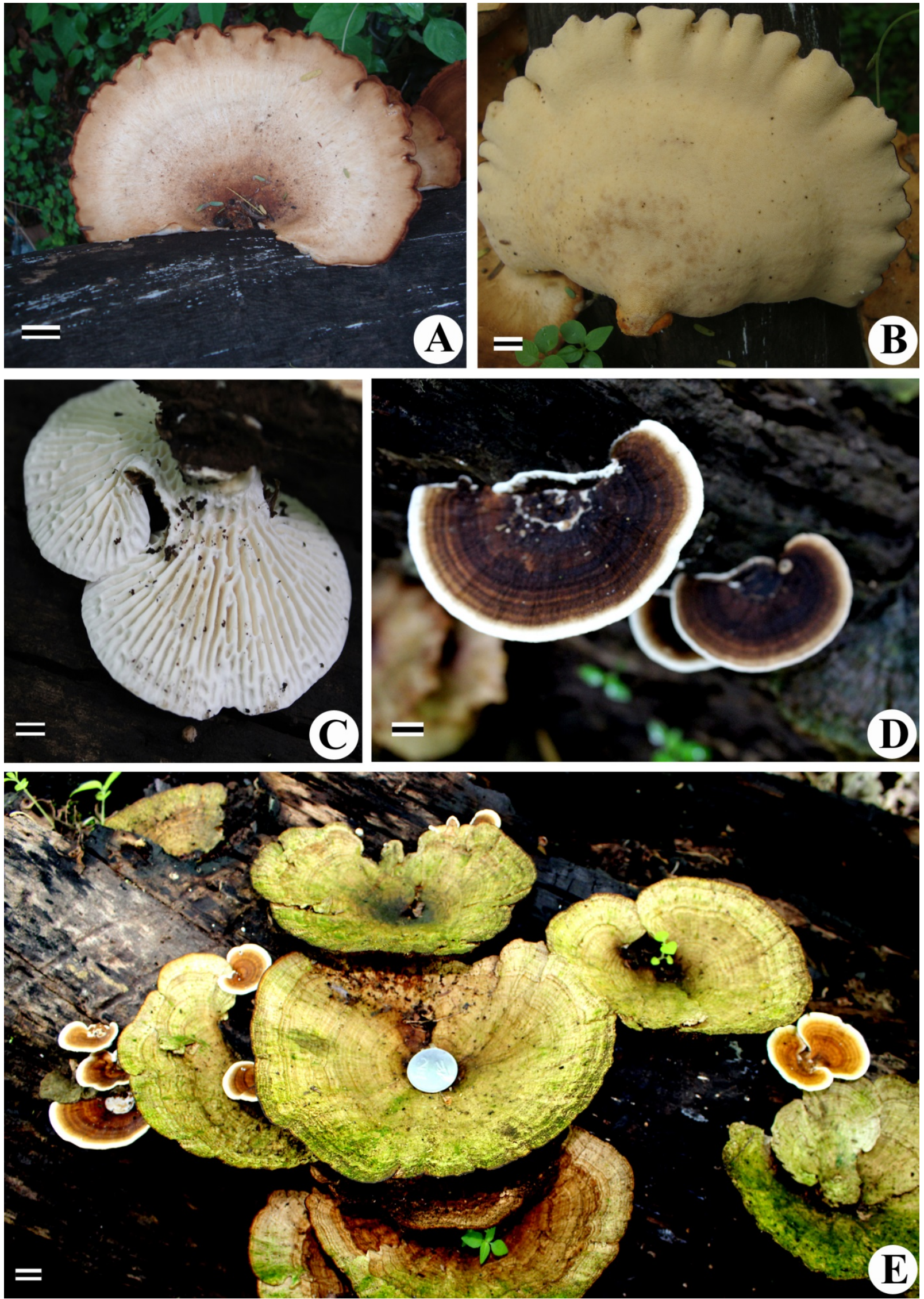

Fig. 1A-D - Fruiting bodies of Favolus grammocephalus (A,B); Lenzites betulina (C,D) and Daedaleopsis confragosa (E). Scale bar: $A-D=10 \mathrm{~mm}, \mathrm{E}: \mathrm{bar}=15 \mathrm{~mm}$

but very few on saprophytic fungi occurring in the state $(1,2,14,16)$. Rajput et al. (20) compiled the first checklist for the state and reported 334 species. Therefore, it is essential to explore the diversity of such important group of organisms. In continuation of previous work, the present study is therefore, aimed to report the status and diversity of Polyporaceae from the Gujarat state. 


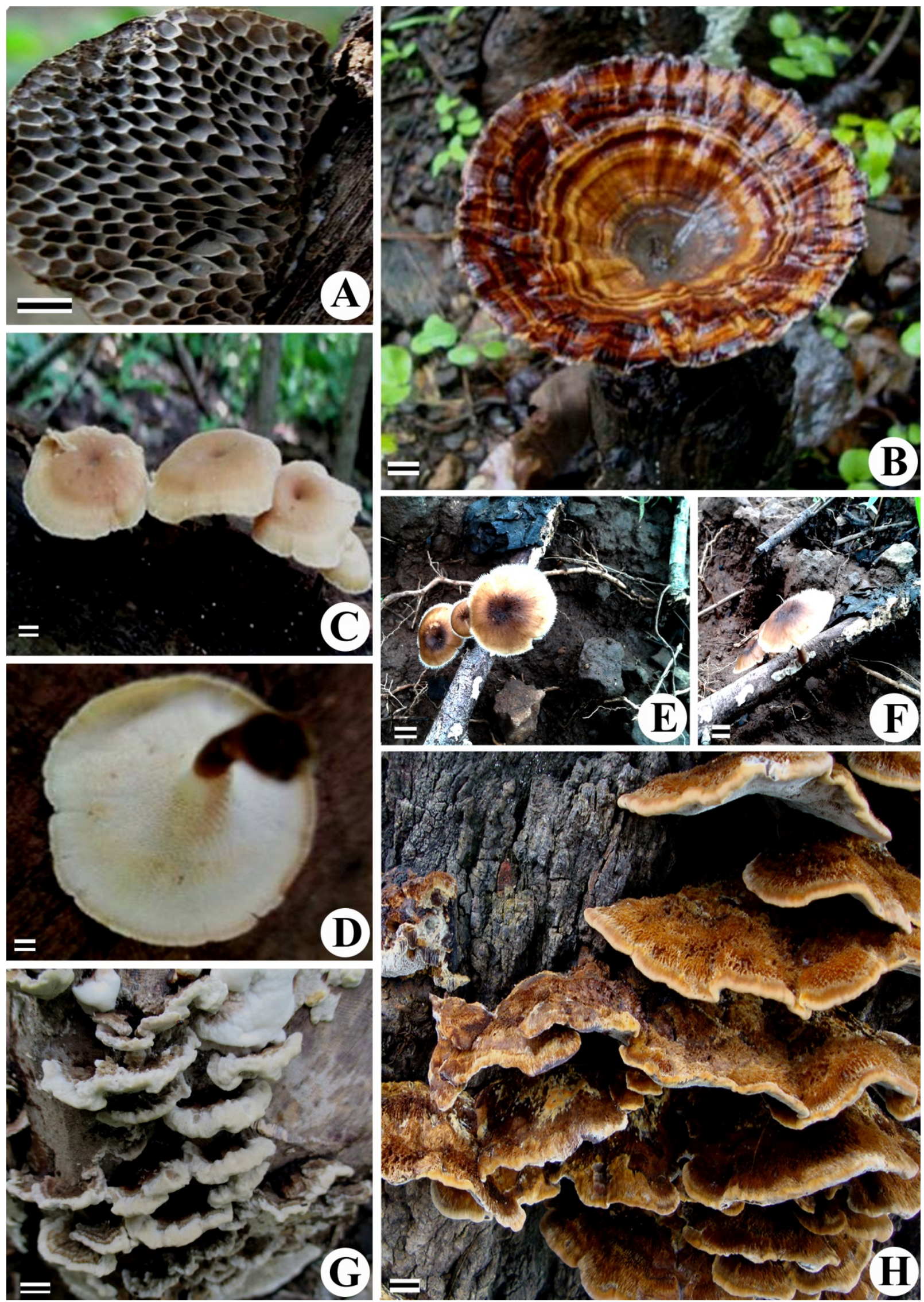

Fig. 2A-H - Fungal fruiting bodies. A: Trametes apiaria, B: Microporus xanthopus, C,D: Polyporus badius, E, F: Polyporus arcularius, G: Tremetes versicolor, H: Trametes trogii Figure 2A, B, C, E, F: Scale bar $=10 \mathrm{~mm}$, D: Scale bar $=5 \mathrm{~mm}, \mathrm{D}, \mathrm{G}$ : Scale bar $=5 \mathrm{~mm}$, H: Scale bar $=15 \mathrm{~mm}$.

\section{Materials and Methods}

Study area: Field work was carried out throughout the state of Gujarat, including undisturbed forests, secondary forests, agricultural fields, waste lands, wetlands, arid and semi-arid regions and bush fallow. Collection of fungal specimen started with the initiation of 

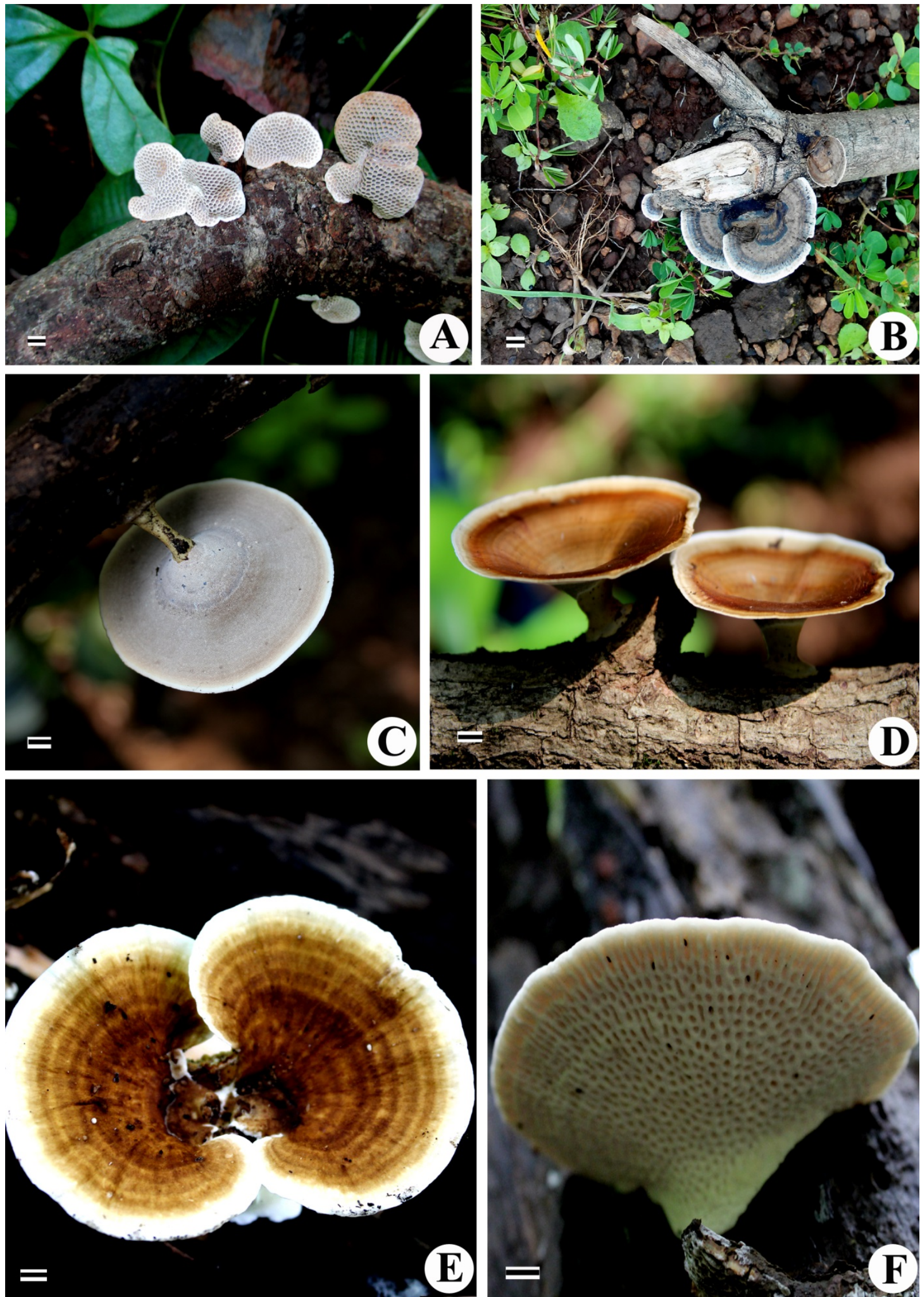

Fig. 3A- F- Fungal fruiting bodies. A, B: Daedaleopsis nitida (syn. Hexagonia nitida), C, D: Trametes vernicipes (syn. Microporus vernicipes), E, F: Lenzites elegans, Figure 3A, B: Scale bar $=10 \mathrm{~mm}, \mathrm{C}, \mathrm{D}, \mathrm{E}, \mathrm{F}$ : Scale bar $=5 \mathrm{~mm}$.

Material Collection: Small parts of the fruiting bodies collected from the field were inoculated on PDA or MEA media. For establishing the cultures, fruiting bodies were suitably trimmed and surface sterilized by $0.1 \% \mathrm{HgCl}_{2}$ for $40-45$ seconds, washed thoroughly with distilled water and treatment with $70 \%$ ethanol for a few seconds. Subsequently, these samples were inoculated on Potato Dextrose 

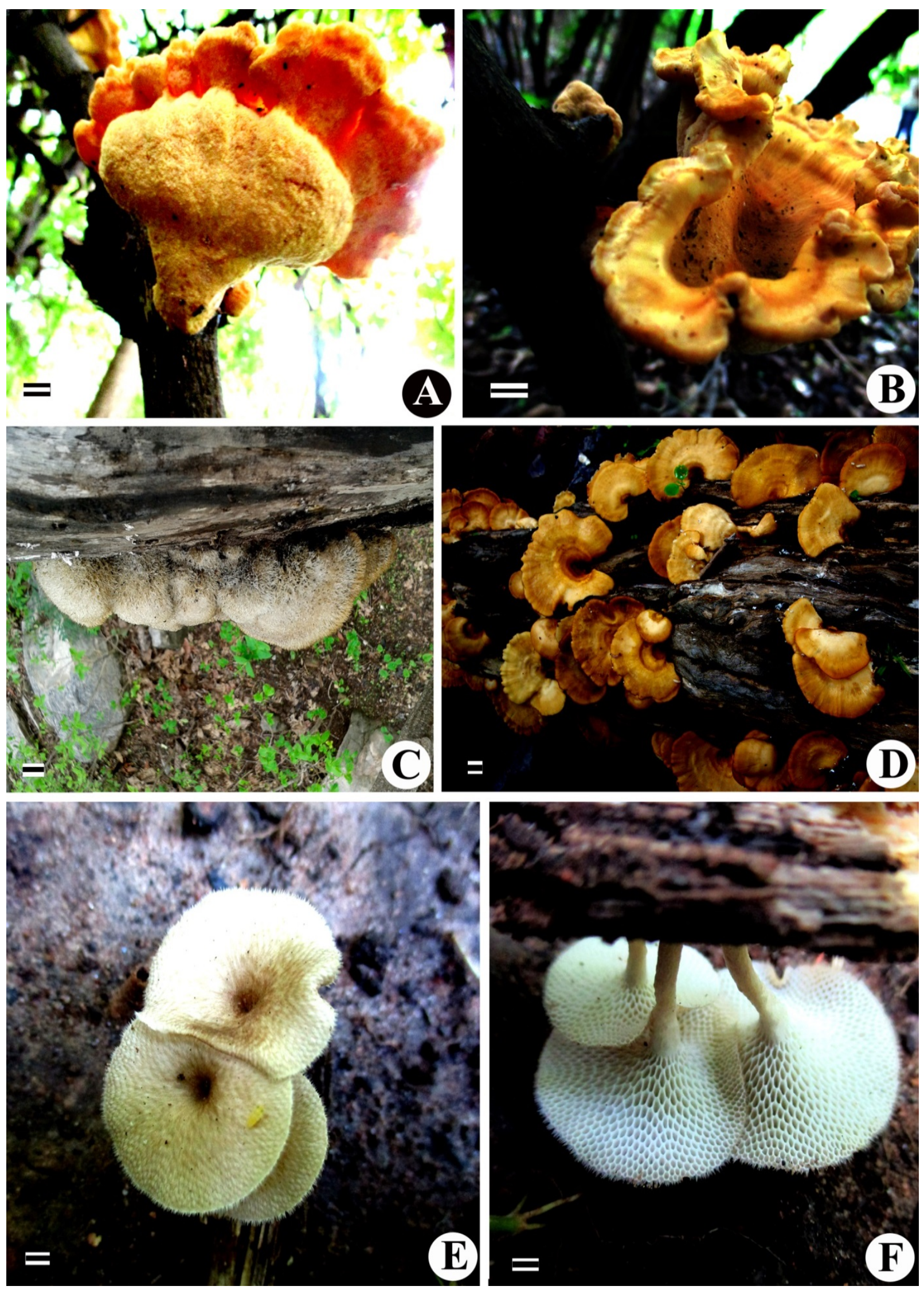

Fig. 4A- F- Fungal fruiting bodies. A, B: Laetiporus sulphureus, C: Coriolopsis gallica D: Polyporus varius E, F: Polyporus tricholoma, Figure 4A, B: Scale bar $=10 \mathrm{~mm}, \mathrm{C}, \mathrm{D}:$ Scale bar $=5 \mathrm{~mm}$ E,F: Scale bar $=5 \mathrm{~mm}$.

Agar (PDA) and Malt Extract Agar (MEA) media and incubated at $27^{\circ} \mathrm{C}$. Pure cultures were established by serial transfer and stored at $4^{\circ} \mathrm{C}$ in refrigerator for further studies. Mycelia and spore characteristics were studied by staining with $1 \%$ aqueous solution of Congo red and mounted in 3\% aqueous $\mathrm{KOH}$ or stained with lactophenol-cotton blue as a staining and mounting medium. Basidiomes were studied under Leica stereo zoom microscope, while hand sections of fruiting bodies 
were observed under Leica tri-nocular (DME 2000) research microscope. All specimens were examined on the basis of their morphological characteristics and identified with the help of available literature $(4,22,23,25)$, New Zealand Fungi database, Species Fungorum and MushroomExpert.com. Doubtful specimens (Polyporus tricholoma, Lenzites betulina, Trametes vernicipes [syn. Microporus vernicipes], Trametes hirsuta) were processed for molecular identification.

Molecular identification: Genomic DNA was extracted by conventional method (19) as well as using Plant/Fungi DNA isolation kit (Sigma Cat\# E5038) from the fresh fruiting bodies or fresh mycelia from one week old fungal cultures. PCR was carried out using $1 \mathrm{X}$ final concentration of Ready Mix $^{\mathrm{TM}}$ Taq PCR Reaction Mix (Sigma) and template DNA (50 $\mathrm{ng} / \mu \mathrm{l})$. Amplification of the DNA was performed by using Thermal cycler (Applied Biosystems Veriti ${ }^{\circledR}$ ) and the ITS region was amplified by PCR machine using the primers ITS 1 and ITS 4 as described by White et al. (28). The amplified products were purified using Purelink ${ }^{\mathrm{TM}}$ Quick PCR Purification kit (Cat\# K310001) and purified products were sent for sequencing to Eurrofins Genomics India Pvt. Ltd., Bangalore.

Sequence data obtained after sequencing was subjected to sequence match analysis using Basic Local Alignment Search Tool (BLAST) on NCBI for identification of fungal species. Identification was done by $99 \%$ base-pair match of the sequence obtained to the closest available reference sequences. After the preliminary analysis, the sequence was submitted to NCBI by using BankIt tool and also submitted to BOLD SYSTEMS according to the guidelines provided on the BOLD website (http://www.boldsystems.org/). After molecular identification, characteristic features of identified species were also compared with the available literature.

\section{Result and Discussion}

Fungal diversity of the western part of India with special reference to the Gujarat state is poorly investigated (20). There are a few sporadic reports on the fungal diversity of the state, but these are either reports from medical colleges on human pathogens or from agricultural universities on plant pathogens. Saprophytic fungi, an important component of forest ecosystems have largely been ignored by researchers. Fungi play an important role in mineralization processes and carbon recycling of various carbohydrates and polysaccharides stored in plant cell walls $(10,21)$. Sporadic reports on wood rot fungi for the state are available $(1,2,14,16)$ but extensive studies on this group is lacking. Rajput et al. (20) compiled the first checklist on the basis of their own field survey and available literature on the fungal diversity of the state and reported 334 species. Koyani et al. (15) and Vasava et al. (26-27) documented the distribution and diversity of the Family Xylariaceae, Myxomycetes and Agaricaceae. Present study is therefore aimed to report the status and diversity of Polyporaceae from Gujarat state on the basis of our own fieldwork and available literature. The current study though preliminary makes an essential contribution to the fungal diversity of the Gujarat State. Still further studies along similar line to document the fungal diversity of the state are essential.

Supplementary Table 1 enlists 37 species belonging 20 genera of the family Polyporaceae on the basis of available literature and our own collections (Fig 1-4) from different biogeographic regions of Gujarat. The most represented genera of the family are Trametes, Microporus, Polyporus, Lentinus, Lenzites, Coriolopsis while Trametes is having maximum number with 11 species. From the total number of species, five species viz. Favolus grammocephalus, Lentinus squarrosulus, Polyporus leprieurii, Panus conchatus and Trametes trogii are being reported for the first time from the western part of India.

\section{Competing interests}

The authors have declared that no competing interests exist.

\section{Authors contributions}

KSR conceived the idea; KSR \& AMV prepared the manuscript. Field visit, collection and identification of specimen was done by AMV, RDK and RSP.

\section{Acknowledgements}

Authors are thankful to the Gujarat Biodiversity Board (GBB) for the financial support and Range forest officers, Deputy Conservators of Forest, Government of Gujarat for the necessary permissions. Thanks are also due to Gujarat State Biotechnology Mission (GSBTM) for providing facilities for molecular studies. Authors also thank the anonymous reviewers for their valuable suggestions on previous version of the manuscript.

\section{References}

1. Arya A. New and interesting records of basidiomycetous fungi from Gujarat, India. In: Srivastava PC, editor. Vistas in Palaeobotany and Plant Morphology: Evolutionary and Environmental Perspectives, Prof D. D. Pant Memorial Volume. UP Offset, Lucknow, India; 2004. pp 321-327.

2. Arya A, Albert S, Nagdesi PK. New and interesting records of Basidiomycetous fungi from Ratanmahal Wildlife Sanctuary, Gujarat, India. Mycology and Plant Pathology 2008;38: 221-226.

3. Assudani HJ, Pandya JM, Sarvan RR, Sapre AM, Gupta AR, Mehta SJ. Etiological diagnosis of microbial keratitis in a tertiary care hospital in 
Gujarat. National Journal of Medical Research 2013; 3:60-62.

4. Bakshi BK. Indian Polyporaceae. Indian Council of Agricultural Research, New Delhi; 1971. 246 pp.

5. Berbee ML, Taylor JW. Fungal Molecular Evolution: Gene Trees and Geologic Time. The Mycota: a comprehensive treatise on fungi as experimental systems for basic and applied research. Volume VII: Systematics and Evolution, Part B; 2001. pp.229-245.

6. Bhavsar HK, Modi DJ, Sood NK, Shah H. A study of superficial mycoses with clinical mycological profile in tertiary care hospital in Ahmedabad, Gujarat. National Journal of Medical Research 2012; 2(2): 160164.

7. Boddy L, Watkinson, SC. Wood decomposition, higher fungi, and their role in nutrient redistribution. Canadian Journal of Botany 1995; 73: S1377-S1383. https://doi.org/10.1139/b95-400

8. Dhingani JC, Solanki KU, Kansara SS. Management of root rot disease [Macrophomina phaseolina (Tassi.) Goid] of chickpea through botanicals and oil cakes. The Bioscan 2013; 8(3): 739-74.

9. Gajjar DU, Pal AK, Parmar TJ, Arora AI, Ganatra DA, Kayastha FB, Ghadadra BK, Vasavada AR. Fungal scleral keratitis caused by Phomopsis phoenicicola. Journal of Clinical Microbiology 2011; 49: 2365-2368. https://doi.org/10.1128/JCM.02449-10

10. Fazio AT, Papinutti L, Gómez BA, Parera SD, Rodríguez RA, Siracusano G, Maier MS. Fungal deterioration of a Jesuit South American polychrome wood sculpture. International Biodeterioration and Biodegradation 2010; 64: 694701. https://doi.org/10.1016/j.ibiod.2010.04.012

11. Kayastha B, Ghadadra BK, Vasavada AR. Fungal scleral keratitis caused by Phomopsis phoenicicola. Journal of Clinical Microbiology 2011; 49: 2365-2368. https://doi.org/10.1128/JCM.02449-10

12. Hawksworth DL. The magnitude of fungal diversity: the 1.5 million species estimate revisited. Mycological Research 2001; 105: 1422-1432. https://doi.org/10.1017/S0953756201004725

13. Kirk PM, Cannon PF, David JC, Stalpers JA. Ainsworth \& Bisby's Dictionary of the Fungi, 9th edition. CABI Publishing; 2001.

14. Korat C, Chopada G, John P. Studies on biodiversity of fleshy fungi in Navsari (South Gujarat), India. International Journal of Biodiversity and Conservation 2013; 5(8): 508-514.

15. Koyani RD, Patel HR, Vasava AM, Rajput KS. Xylariaceae: Overview and addition to fungal diversity of Gujarat state. Studies in Fungi 2016; 1(1): 69-79. https://doi.org/10.5943/sif/1/1/6

16. Nagadesi PK, Arya A. Lignocellulolytic activity of wood inhabiting fungi from Ratanmahal Wildlife Sanctuary Gujarat, India. Advanced Biotech. 2012; 12(5): 30-36.

17. Nagadesi PK, Arya A. Rotting of Peltophorum ferrugineum (Decne.) Benth. by pathogenic lignicolous fungi in Rajpipla, Gujarat, India. Journal on New Biological Reports 2013; 2(1): 17-27.

18. Panchal P, Pethani J, Patel D, Rathod S, Shah P. Analysis of various fungal agents in clinically suspected cases of otomycosis. Indian Journal of Basic \& Applied Medical Research 2013; 8: 865-869.

19. Płaza G, Upchurch R, Brigmon R, Whitman W, Ulfig K. Rapid DNA extraction for screening soil filamentous fungi using PCR amplification. Polish Journal of Environmental Studies 2004; 13:315-318.

20. Rajput KS, Koyani RD, Patel HP, Vasava AM, Patel R, Patel A, Singh AP. Preliminary checklist of fungi of Gujarat state, Western India. Current Research in Environmental and Applied Mycology 2015; 5(4): 285306.

21. Sanghvi GV, Koyani RD, Rajput KS. Anatomical characterization of Teak wood (Tectona grandis L.f.) decayed by fungus Chrysosporium asperatum. Journal of Tropical Forest Science 2013; 25: 547-553.

22. Sharma JR. Hymenochaetaceae of India. Botanical Survey of India, Calcutta; 1995.

23. Sen M. Cultural diagnosis of Indian Polyporaceae. Indian Forest Records, Fprest pathology, New Series. with I -VII plates. Forest Research Institute, Dehradun 1973; 2 (11): 277-304.

24. Thaker S, Maharsh R. Growth and development of plant pathogenic fungi in define media. European Journal of Experimental Biology 2012; 2(1): 44-54.

25. Thind KS, Rattan SS. The Polyporaceae of India VIII, Research Bulletin Punjab University. (N.S.) 1971; 22: 27-34.

26. Vasava AM, Koyani RD, Singh AP, Rajput KS. Diversity and distribution of myxomycetes in western part of India, with special reference to the state of Gujarat. Current Research in Environmental \& Applied Mycology 2015; 5(4): 382-389.

27. Vasava AM, Koyani RD, Patel R, Rajput KS. Diversity and distribution of agaricaceae in western part of India with special reference to gujarat state. Journal of Indian Botanical Society 2017; 96(1 \& 2):119-135.

28. White T, Bruns T, Lee S, Taylor J. Amplification and direct sequencing of fungal ribosomal RNA genes for phylogenetics. In: Innis MA, Gelfand DH, Sninsky JJ, White TJ, (Eds) PCR Protocols: a guide to methods and applications. Academic Press, New York, USA; 1990. p. 315-322. https://doi.org/10.1016/B978-0-12372180-8.50042-1

29. Yadav SM, Patil RK, Rai AK, Balai LP, Singh S, Niwas R. A survey: Occurrence of post-harvest rot of aonla and new reported pathogen (Penicillium funiculosum Thom.). Plant Pathology Journal 2013; 12(2): 124-126. https://doi.org/10.3923/ppj.2013.124.126 
Supplementary Table 1: List of species of Polyporaceae reported from different parts of Gujarat in the present study and by the earlier researchers

\begin{tabular}{|c|c|c|c|}
\hline Sr No. & Scientific name & Distribution & Reference \\
\hline 1. & Cerrena unicolor (Bull.) Murrill, J. Mycol. 9(2): 91 (1903) & Ratanmahal & Nagadesi \& Arya 2014 \\
\hline 2. & Coriolopsis aspera (Jungh.) Teng, Chung-kuo Ti Chen-chun, [Fungi of China]: 759 (1963) & Ratanmahal & Arya et al. 2008 \\
\hline 3. & Coriolopsis gallica (Fr.) Ryvarden, Norw. J. Bot. 19: 230 (1973) & Ratanmahal & Nagadesi \& Arya 2014 \\
\hline 4. & Daedalea quercina (L.) Pers., Syn. meth. fung. (Göttingen) 2: 500 (1801) & Ratanmahal & Nagadesi \& Arya 2014 \\
\hline 5. & $\begin{array}{l}\text { Daedaleopsis confragosa (Bolton) J. Schröt., in Cohn, Krypt.-Fl. Schlesien (Breslau) 3.1(25-32): } \\
492 \text { (1888) [1889] }\end{array}$ & $\begin{array}{l}\text { Rajkot, Baroda , Dang, } \\
\text { Junagadh }\end{array}$ & Nagadesi \& Arya 2016 \\
\hline 6. & $\begin{array}{l}\text { Daedaleopsis nitida (Durieu \& Mont.) Zmitr. \& Malysheva, Mikol. Fitopatol. 47(6): } 375 \text { (2013) } \\
\text { (syn. Hexagonia nitida) }\end{array}$ & Dharampur, Ratanmahal & Rajput et al. 2015 \\
\hline 7. & Dichomitus squalens (P. Karst.) D.A. Reid, Revta Biol., Lisb. 5(1-2): 150 (1965) [1964-5] & Junagadh & Rajput et al. 2015 \\
\hline 8. & Earliella scabrosa (Pers.) Gilb. \& Ryvarden, Mycotaxon 22(2): 364 (1985) & Junagadh & Rajput et al. 2015 \\
\hline 9. & Favolus grammocephalus (Berk.) Imazeki, Bull. Tokyo Sci. Mus. 6: 95 (1943) & $\begin{array}{l}\text { Ratanmahal, Dang, } \\
\text { Jessore, Gandhinagar }\end{array}$ & Present study \\
\hline 10. & $\begin{array}{l}\text { Funalia caperata (Berk.) Zmitr. \& Malysheva(Funalia caperata (Berk.) Zmitr. \& Malysheva, } \\
\text { Mikol. Fitopatol. 47(6): } 375 \text { (2013) }\end{array}$ & $\begin{array}{l}\text { Gandhinagar, Junagadh, } \\
\text { Ahwa }\end{array}$ & Rajput et al. 2015 \\
\hline 11. & Hexagonia tenuis (Fr.) Fr., Epicr. syst. mycol. (Upsaliae): 498 (1838) [1836-1838] & Ratanmahal, Dang & Nagadesi \& Arya 2012 \\
\hline 12. & $\begin{array}{l}\text { Leiotrametes lactinea (Berk.) Welti \& Courtec., in Welti, Moreau, Favel, Courtecuisse, Haon, } \\
\text { Navarro, Taussac \& Lesage-Meessen, Fungal Diversity 55(1): } 60 \text { (2012) }\end{array}$ & Ratanmahal & Nagadesi \& Arya 2014 \\
\hline 13. & $\begin{array}{l}\text { Lentinus arcularius (Batsch) Zmitr., International Journal of Medicinal Mushrooms (Redding) } \\
\text { 12(1): } 88 \text { (2010) }\end{array}$ & Dang, Ratanmahal & Rajput et al. 2015 \\
\hline 14. & Lentinus squarrosulus Mont., Annls Sci. Nat., Bot., sér. 2 18: 21 (1842) & Dang & Present Study (GSBTM) \\
\hline 15. & $\begin{array}{l}\text { Lentinus tricholoma (Mont.) Zmitr., International Journal of Medicinal Mushrooms (Redding) } \\
\text { 12(1): } 88 \text { (2010) }\end{array}$ & $\begin{array}{l}\text { Gandhinagar, Rajpipla, } \\
\text { Dang }\end{array}$ & Rajput et al. 2015 \\
\hline
\end{tabular}




\begin{tabular}{|c|c|c|c|}
\hline 16. & Lenzites betulina (L.) Fr., Epicr. syst. mycol. (Upsaliae): 405 (1838) [1836-1838] & Ratanmahal, Junagadh & $\begin{array}{l}\text { Nagadesi \& Arya 2012; } \\
\text { Rajput et al. } 2015\end{array}$ \\
\hline 17. & Lenzites stereoides (Fr.) Ryvarden, Norw. Jl Bot. 19: 232 (1972) & Ratanmahal, Dang & Arya et al.2008 \\
\hline 18. & Laetiporus sulphureus (Bull.) Murrill, Annls mycol. 18(1/3): 51 (1920) & Dang, Junagadh, Vansda & $\begin{array}{l}\text { Korat et al. 2013; } \\
\text { Rajput et al. } 2015\end{array}$ \\
\hline 19. & $\begin{array}{l}\text { Microporus affinis var. glabriceps Nagdesi \& Arya (Microporus affinis var. glabriceps Nagadesi } \\
\text { \& A. Arya, Mycosphere 3(6): } 1000 \text { (2012) }\end{array}$ & Ratanmahal & Nagadesi \& Arya 2012 \\
\hline 20. & Microporus alboater (Henn.) Kuntze, Revis. gen. pl. (Leipzig) 3(2): 494 (1898) & Ratanmahal & Nagadesi \& Arya 2012 \\
\hline 21. & Microporus ochrotinctus (Berk. \& M.A. Curtis) Kuntze, Revis. gen. pl. (Leipzig) 3(2): 496 (1898) & Gandhinagar, Junagadh & Rajput et al. 2015 \\
\hline 22. & Microporus xanthopus (Fr.) Kuntze, Revis. gen. pl. (Leipzig) 3(2): 494 (1898) & Junagadh, Pavagdh & Rajput et al. 2015 \\
\hline 23. & $\begin{array}{l}\text { Navisporus floccosus (Bres.) Ryvarden [as 'floccosa'], in Ryvarden \& Johansen, Prelim. Polyp. Fl. } \\
\text { E. Afr. (Oslo): } 443 \text { (1980) }\end{array}$ & Ratanmahal & Arya et al. 2008 \\
\hline 24. & Neolentinus kauffmanii (A.H. Sm.) Redhead \& Ginns, Trans. Mycol. Soc. Japan 26(3): 357 (1985) & Polo forest & Rajput et al. 2015 \\
\hline 25. & Panus conchatus (Bull.) Fr., Epicr. syst. mycol. (Upsaliae): 396 (1838) [1836-1838] & Baroda , Dang & Present study \\
\hline 26. & Phellinus badius (Cooke) G. Cunn., Bull. N.Z. Dept. Sci. Industr. Res., Pl. Dis. Div. 164: 273 (1965) & Rajpipla & Nagadesi \& Arya 2013 \\
\hline 27. & Polyporus leprieurii Mont., Annls Sci. Nat., Bot., sér. 2 13: 203 (1840) & Vansada & Present study (GSBTM) \\
\hline 28. & $\begin{array}{l}\text { Trametes apiaria (Pers.) Zmitr., Wasser \& Ezhov, International Journal of Medicinal } \\
\text { Mushrooms (Redding) 14(3): } 317 \text { (2012) }\end{array}$ & Ratanmahal & Nagadesi \& Arya 2014 \\
\hline 29. & Trametes elegans (Spreng.) Fr., Epicr. syst. mycol. (Upsaliae): 492 (1838) [1836-1838] & $\begin{array}{l}\text { Dang, Junagadh, } \\
\text { Ratanmahal }\end{array}$ & Rajput et al. 2015 \\
\hline 30. & $\begin{array}{l}\text { Trametes flavida (Lév.) Zmitr., Wasser \& Ezhov, International Journal of Medicinal Mushrooms } \\
\text { (Redding) 14(3): } 310 \text { (2012) }\end{array}$ & Junagadh, Polo forest & Rajput et al. 2015 \\
\hline 31. & Trametes gibbosa (Pers.) Fr., Epicr. syst. mycol. (Upsaliae): 492 (1838) [1836-1838] & Ratanmahal & Nagadesi \& Arya 2014 \\
\hline 32. & Trametes hirsuta (Wulfen) Lloyd, Mycol. Writ. 7(Letter 73): 1319 (1924) & Junagadh & Rajput et al. 2015 \\
\hline
\end{tabular}

Vasava et al. Supplementary Table 1. Plant Science Today (2018) 5(1): 32-38 


\begin{tabular}{|c|c|c|c|}
\hline 33. & Trametes ljubarskyi Pilát, Bull. trimest. Soc. mycol. Fr. 52(3): 309 (1937) [1936] & Junagadh & Rajput et al. 2015 \\
\hline 34. & Trametes palisotii (Fr.) Imazeki, Bull. Gov. Forest Exp. Stn Tokyo 57: 120 (1952) & Ratanmahal & Nagadesi \& Arya 2012 \\
\hline 35. & Trametes trogii Berk., in Trog, Mittheil. d. schweiz. Naturf. Ges. in Bern 2: 52 (1850) & Junagadh & Present study \\
\hline 36. & $\begin{array}{l}\text { Trametes vernicipes (Berk.) Zmitr., Wasser \& Ezhov, International Journal of Medicinal } \\
\text { Mushrooms (Redding) 14(3): } 312 \text { (2012). (syn. Microporus vernicipes) }\end{array}$ & $\begin{array}{l}\text { Waghai, Saputara, } \\
\text { Junagadh }\end{array}$ & Rajput et al. 2015 \\
\hline 37. & Trametes versicolor (L.) Lloyd, Mycol. Notes (Cincinnati) 65: 1045 (1921) [1920] & $\begin{array}{l}\text { Navsari, Ratanmahal, } \\
\text { Junagadh }\end{array}$ & $\begin{array}{l}\text { Korat et al. 2013; Nagadesi \& } \\
\text { Arya 2012; Rajput et al. } 2015\end{array}$ \\
\hline
\end{tabular}

\section{Citation}

Vasava A M, Patel R S, Koyani R D, Rajput K S. Distribution and diversity of Polyporaceae in Western India: An overview and addition to mycoflora of the Gujarat state. Plant Science Today 2018;5(1):32-38. https://dx.doi.org/10.14719/pst.2018.5.1.353 